\title{
Getting Through the Hard Times Together? Chinese Workers and Unions Respond to the Economic Crisis
}

\author{
Eli Friedman \\ Cornell University
}

\begin{abstract}
How do post-socialist unions respond to market crisis? And what are the implications of this response for labor representation? Drawing on literature on post-socialist labor and union democracy, I argue that economic crisis affects not just labor-capital and labor-state relations, but also the relationship between union representatives and workers. Such a dynamic is highlighted by an empirical account of the divergent activities of workers and All-China Federation of Trade Unions (ACFTU) unions in China following the economic crisis of 2008. While the union responded to mass unemployment with an administrative and policy-oriented strategy, workers took to the streets in increasing numbers. This divergence led to several instances of conflict, and, by 2010, it was possible to detect small but significant shifts in the union's approach to dealing with labor unrest.
\end{abstract}

Keywords: All-China Federation of Trade Unions; China; economic crisis; protest post-socialist; strikes; union democracy

\section{Introduction}

While there is now a body of literature on post-socialist trade unions and the challenges they face in dealing with market reforms, we do not yet have an understanding of how such unions respond to economic crisis. This is in large part due to the fact that prior to 2008, the last systemic crisis was in the 1970s, at which time state socialism and the command economy were still firmly entrenched in China and the Soviet Union, among other countries. But in the aftermath of 2008, we are now in a position to ask: How do post-socialist unions fare in their first properly capitalist crisis? Based on an analysis of the political activities of Chinese migrant workers and the All-China Federation of Trade Unions (ACFTU) during 2008-2010, I argue that the external shock of economic crisis serves to intensify the internal conflict within labor between insurgent workers and their union representatives. Such a dynamic is likely to be more prevalent for post-socialist unions - disconnected as they are from the rank and file - than would be the case for more democratic unions. And yet the basic insight that economic crisis can lead to new tensions between union membership and representatives may be more broadly applicable.

Labor scholars and practitioners alike have long debated the consequences of economic crises for the labor movement. Some, following in the vein of Communist Manifesto (Marx, 1978), hold that recurrent crises of capitalism are primary opportunities for advancing the interests of the working class. In this view, economic crisis results in mass unemployment, which provides a coercive incentive to organization, mobilization, and confrontation with capital, which then leads to a progressive strengthening of the political power of labor. Skeptical of this view, others contend that convulsions in the market disproportionately affect workers, and that labor is only able to fight defensive battles under such conditions. And it is this pattern of scholarship that holds for work on the most recent economic crisis. A 2010 forum in Socio-Economic Review asked a group of labor scholars from Europe and the US the following question: 'Does 
the global financial crisis mark a turning point for labor?' In his introduction, Lucio Baccaro says that 'the six contributions gathered in this symposium are really six different ways of answering "No!" to the question, more or less resoundingly and emphatically' (2010: 342). Similarly, Birnbaum finds that, 'The shock did not generate a European wave of protest, much less widespread social turmoil. The European Left could not organize protest, since it was divided, disoriented, and ideologically disarmed' (2010: 25), concluding that social democracy as a whole is seriously threatened. Chris Tilly talks about the 'missed opportunity' for the US labor movement, as the AFL-CIO and Change to Win federations focused largely on policy proposals that by and large failed to materialize (Tilly, 2010).

But for post-socialist unions, weakened as they are by institutional constraints (Crowley, 2004; Crowley and Ost, 2001), the question is not one of a 'missed opportunity', since such organizations do not seek to increase their coercive power vis-a-vis employers or the state. Indeed, it has been these unions' ongoing subordination to political parties (particularly in China and Vietnam) that constrains their activities in the political sphere and causes them to ally with management at the enterprise level (Clarke and Pringle, 2009). But if there is no expectation that post-socialist unions might use increasing levels of discontent among membership as a basis for increasing their independent power, how might they respond? Can economic crisis create a severe enough external shock to force the unions to abandon their complacency and engage in serious reform, or will existing institutional constraints prevent this from happening? And what are the implications of the union response for their representative relationship with members?

In the case at hand, I analyze how the economic crisis that intensified in late 2008 affected the relationship between Chinese workers and the state-run ACFTU. The crisis did in fact provide a coercive incentive for worker mobilization, as widespread unemployment in the export-oriented sectors led to a massive upsurge in legal disputes, strikes, demonstrations and riots. The ACFTU, on the other hand, unveiled an approach they promoted as 'Getting Through the Hard Times Together' (referenced in the title of this article). This slogan was an attempt on the part of the union to use the only power they had - that of persuasion - to convince labor and capital to each make compromises in response to the crisis. So, while worker radicalism expanded in response to the downturn, the unions remained committed to an administrative approach to resolving conflict - one that assumed coincidental interests of employees and employers. As a result, I argue that the representative relationship between the ACFTU and migrant workers is one characterized by divergence and conflict. However, as worker resistance remained high during the years 2008-2010, the union's approach shifted gradually, leading to a series of new proposals for reform in mid- to late 2010. Thus, I argue that crisis may serve to reveal and intensify underlying tensions within union representation of workers, in turn transforming this relationship - particularly in a post-socialist context. China is indeed an extreme case in the sense that union representatives are highly illegitimate among their constituency; but it is precisely the exaggerated nature of this case that brings the dynamic into clearer focus. With unions in many countries increasingly integrated into structures of the state and unable to resist market- ization, similar dynamics are likely to occur in other places as well.

I will first briefly discuss theories of union democracy and representation, and how such relationships may be affected by economic crisis. After describing the activities of ACFTU-subordinate unions in the few years leading up to 2008, I will outline the distinct responses of the union and workers to the outbreak of the crisis, drawing on a few cases 
to illustrate my main points. Finally, I provide an account of the strike wave that broke out in May of this year, followed by concluding remarks.

\section{Union Representation and Economic Crisis}

The question of union democracy has been a primary area of inquiry for many decades. Many, drawing on the work of Max Weber (1946) and Robert Michels (1962), have argued that even unions that proclaim adherence to radical democracy will become increasingly oligarchic over time. Other scholars have identified particular instances in which unions can be more democratic, depending on sector (Lipset et al., 1956), internal rules and electoral forms (StepanNorris, 1997), or the particular dynamics between local and national leadership (Voss and Sherman, 2000). In China, however, it is not that unions have become less democratic over time, but rather that they were created in toto by the state without the consent or involvement of the membership.

Borrowing terms originally used by Weber, I argue for using two radically antithetical (Weber, 1978: 293) ideal types of representation in conceptualizing the problem. At one end of the spectrum we have 'instructed representation', in which representatives are directly elected or selected by lot, and are then subject to unconditional recall by membership (Weber, 1978: 293). At the other end is 'appropriated representation' (Weber, 1978: 292), a term Weber hardly develops at all. I, however, refer to this ideal type as a situation in which the rights of representation of an entire social class are unilaterally assigned to a single organization without the consent or involvement of the group in question - that is, the representative claim is 'appropriated' rather than 'earned.' The questions to ask when trying to determine how to characterize a particular organization are: To what extent does the organization derive its legitimacy from the active recognition of its membership versus other sources (especially the state)? Do workers recognize the union as their representative? Does the state or employers? Of course, such ideal types do not exist empirically, nor is the type of representation static, as the sources of legitimacy can shift depending on a variety of conditions.

Now, how might we expect these two types of unions - those characterized by instructed and appropriated representation, respectively - to behave in response to the external shock of an economic crisis? And what of the practical activity of their memberships? In normal times, we would expect a tighter alignment in the activities of union representatives and membership in those unions characterized by instructed representation, while there would be greater divergence under conditions of appropriated representation. An economic crisis is a severe external shock particularly when it leads to mass unemployment or a reduction in pay, benefits, and so on, for employees. Specifically, in postsocialist unions such as the ACFTU - as close an empirical approximation of the ideal type of appropriated representation as can be found - union leadership is highly subordinate to employers at the level of the firm. It is precisely this institutionalized arrangement that enhances the likelihood that the practices of the membership will become radicalized, as there is no regularized mechanism for dealing with layoffs, reductions in hours and benefits, and other issues that might arise in a crisis. Since workers have no capacity to recall representatives, there is little incentive for union officialdom to take risks and side with radical workers against employers. We can see how such practical divergence between union officials and workers can (and did) lead to internal conflict. 
We will soon see that in China, the union's 'comfortable' (Clarke and Pringle, 2009: 88) response to the crisis, based on 'lobbying the state for protective regulations and protective legislation and relying on state agencies to monitor and enforce the laws and regulations' (Clarke and Pringle, 2009: 88), was unable to staunch a rising tide of worker discontent. Thus, while ACFTU unions were highly constrained by existing institutional arrangements, economic crisis led to increasing autonomous worker insurgency. This divergence in the activities of represented and representer in turn transformed the relationship, such that by 2010, many union officials were calling for more effective collective bargaining laws and a legalization of strikes.

\section{The ACFTU Before the Crisis}

The ACFTU claims a membership of 258 million, making it the largest national union federation in the world by an incredibly large margin. The structure of the union mirrors that of the Communist Party, with union federations established at the national, provincial and municipal levels, as well as frequently at the county, township, district and even street level (Lee, 1986). Finally, there are the 'grassroots-level' unions, which refers to the organization within the enterprise. At every level, union organizations are subject to dual control, both by the structurally horizontal Party organization (if one exists), as well as the immediately superior level of the union hierarchy.

ACFTU-subordinate unions' capacity to actively formulate and advance the interests of their membership is highly curtailed, as even a cursory analysis of the formal administrative arrangements reveals (Chen, 2009). The union's constitution spells out that it is formally subordinate to the Communist Party. While a small percentage of members do pay voluntary dues, the majority of funding for operational expenses comes from a $2 \%$ payroll tax on employers and in direct funding from the state. Elections for union leadership are highly scripted affairs, and regular union cadres - to say nothing of rank-and-file workers - cannot meaningfully express their wishes through such mechanisms (Howell, 2006), even in the most likely cases (Yu, 2008). Management exercises inordinate control over enterprise-level unions, and these organizations are usually chaired by someone from high levels of management (Ng and Warner, 1998). Although unions sometimes assist workers in pursuing cases in court (Chen, 2004), lack of freedom of association means that there has been little success with collective negotiations (Chen, 2007; Clarke et al., 2004). In the event that an activist union chair does manage to get into power, their activities are highly constrained, since they are simultaneously enterprise employees and there is little protection against managerial capriciousness (Chen, 2003).

And yet, Chinese union officials frequently argue that what they lack in independence, they make up for in access to state power. When Hu Jintao and Wen Jiabao came to power in 2002 promising greater social and economic equality, union leadership was poised to hold a greater say in policymaking. Union federation chairs increasingly were assigned joint posts as vice-directors of legislative bodies at various levels of the state. And union leadership began openly calling for establishing branches in private and foreign-owned enterprises, significant sectors of the economy that were almost completely unorganized. The Trade Union Law of 2001 and the Labor Contract Law passed in 2007 assigned greater rights to the unions in representing workers (Wang et al., 2009). 


\section{The Crisis Hits China}

Although China's overall dependence on exports is sometimes overstated (Anderson, 2007), relatively developed coastal provinces are more vulnerable to a fall in foreign demand than interior provinces (He and Zhang, 2010). Thus, the financial crisis was bound to have a large impact on these regional economies. In November 2008, China's exports fell for the first time in seven years, indicating weakness in this crucial sector (Associated Press, 2008b). In December, it was revealed that in Guangdong province alone, 15,661 small and medium enterprises had closed down that year (Yangchengwanbao, 2008). Some industries were hit particularly hard, with government statistics revealing that two-thirds of small toy manufacturers closed in the first nine months of the year (Bloomberg, 2008).

Unsurprisingly, these dramatic economic changes had a huge impact on employment. By February of 2009, it was estimated that a staggering 20 million migrant workers returned to the countryside because they were unable to find work (The Guardian, 2009). ${ }^{1}$ In many places throughout the country, bosses in financial trouble skipped town, frequently leaving their employees with months of unpaid wages. The municipal authorities in Dongguan admitted that in the months of September and October alone, 117 bosses that owed back wages 'went into hiding', affecting approximately 20,000 workers (Nanfangdushibao, 2008). The problem of Korean bosses leaving town without paying employees their owed wages became so acute in Shandong province that Korean government officials held talks with their Chinese counterparts and promised to investigate the problem (Reuters, 2008). Although factors such as the newly passed Labor Contract Law and rising wages were in part blamed for the decline of the export sector, the sharpening of the crisis in the West held immediate and severe consequences for the stability of employment in China.

\section{Worker Resistance Spreads}

The deepening of the crisis dramatically increased the quantity of worker protest, even if it did not immediately change the quality of such resistance. The number of strikes and officially mediated labor disputes had been increasing rapidly for at least 15 years, and yet the growth in conflicts accelerated yet again in 2008. The number of 'mass incidents' (a category including all protests, a very significant portion of which are worker-related) increased rapidly throughout the 1990 s and 2000s, eventually reaching 87,000 in 2005 . Subsequently, the government ceased publicizing such numbers, but there were unofficial reports that 2008 saw an astonishing 120,000 such incidents. By 2010, state spending on internal security forces nearly matched spending on military defense. The government does publicize the numbers for officially mediated labor disputes, which increased rapidly throughout the 1990s. However, as indicated in Figure 1, there was a huge increase in the number of cases in 2008, with only a slight decline in 2009. 
Figure 1 Labor dispute cases, 1996-2009

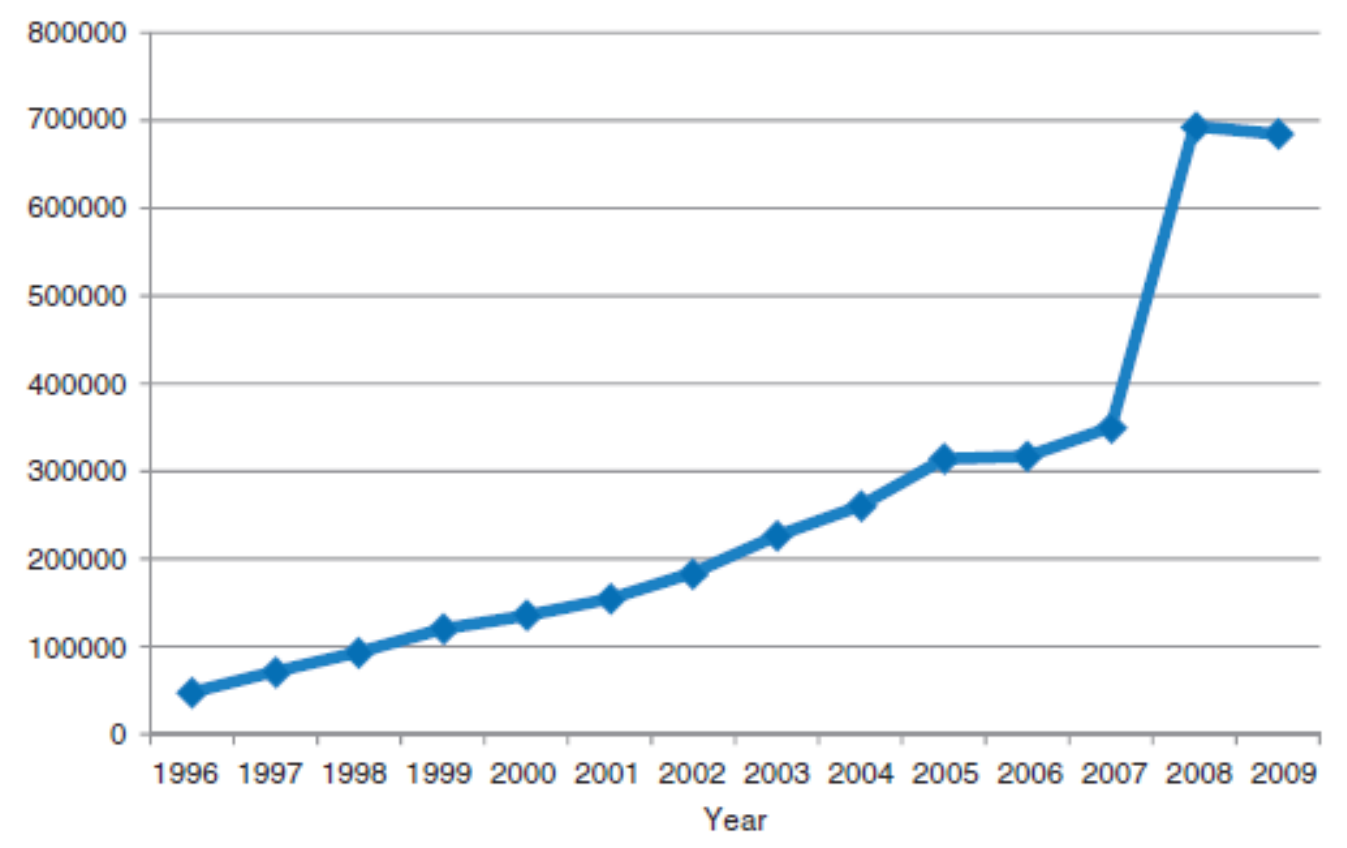

Source: National Bureau of Statistics (NBS) and Ministry of Human Resources and Social Security (MOHRSS) (2010).

While the economic crisis was a key factor behind the increase in disputes, the 2008 enactment of the Labor Contract Law and the Labor Dispute Mediation and Arbitration Law also had a major impact. The Labor Contract Law had been much discussed in the media, and likely raised workers' awareness about various legal rights. One of the primary intentions behind the law was to ensure that all workers were provided contracts, something that had not happened in many industries. The state is unable to process official labor disputes if there is no contract. And perhaps most importantly, the Labor Dispute Mediation and Arbitration Law eliminated or greatly reduced the costs for workers to file a dispute. Thus, in addition to the severe economic shock, the (coincidental) enactment of these two laws also increased the number of disputes.

But official dispute resolution mechanisms frequently failed to provide justice in a timely manner for desperate workers, many of whom had just been thrown out of work without any severance payments. Even before the crisis, it was not unusual for workers to have to wait for more than a year to resolve a simple non-payment of wages case. Even though rulings are often given in workers' favor, waiting so long for a resolution can be quite a hardship for migrants who do not have access to social services in cities. As one migrant worker from Shenzhen said after the owner of the factory disappeared without paying back wages, 'We are aware of our rights, but we don't have enough time to go to court. We just want to get paid and go home before the [Chinese New Year] holiday' (Wall Street Journal, 2009).

As Ching Kwan Lee (2007) has noted, migrant workers tend to become radicalized after the legal system has failed to deliver justice. This pattern held in 2008 as a wave of worker insurgency swept through the country's exportprocessing zones, with workers petitioning government offices, going on strike, blocking roads, rioting, and even committing murder and/or suicide (Chan, 2010). Although there was unrest throughout the country, Dongguan, which was particularly affected by the crisis, saw the greatest outburst of worker protest and violent confrontations with the 
police. In November 2008, the Hong Kong-owned Kaida toy factory was planning on terminating the contracts of several hundred of its workers. Management had made an offer on severance payments that workers were unsatisfied with, and which was likely below what they were legally entitled to. Unable to reach an agreement through informal negotiations, several hundred workers rampaged through the factory, smashing offices and other facilities. When the police turned up to try to control the situation, the scope of the riot expanded. A reported 500 people engaged in property destruction and smashed several police vehicles with as many as 2000 people observing (Guangzhou Ribao, 2008).

While the Kaida riot was perhaps the most spectacular incident of worker protest, resistance appeared in many other factories. Also in Dongguan, hundreds of workers at a suitcase factory were left without months of wages when the Japanese owner disappeared in December (Associated Press, 2008c). Unwilling to take the government's offer of $60 \%$ of their owed wages, riot police blocked them inside the factory until they relented, leading to several violent encounters. At the same time, almost 1000 workers held a peaceful sit-in at an electronics factory in Shanghai over unpaid wages and bonuses (Agence French-Presse, 2008). Even in China's north-west, there were reports of 6000 workers occupying a textile plant (The Sunday Times, 2009).

In some cases, the failure of normalized channels resulted in workers taking much more extreme actions. In February, a desperate migrant worker successfully committed suicide by slitting his wrists at the crowded train station in Guangzhou (Nanfeng Chuang, 2009). Other unemployed migrants set off an explosive at a hotel in nearby Foshan (The Sunday Times, 2009). And a worker at a jewelry factory in Guangzhou murdered two domineering managers before committing suicide. Many workers had already been laid off from this factory without receiving proper severance, and this man likely feared that he would encounter a similar fate.

Here, I have only presented a tiny fragment of the avalanche of worker protest that appeared during the economic crisis. Although the frequency of such protest certainly increased in late 2008 and through 2009, the basic character of worker insurgency did not change. Although difficult to verify, there may have been a somewhat more violent character to these protests than before the crisis. But, in general, in these defensive acts workers were merely attempting to secure things to which they were legally entitled. By and large, protests remained cellular and made only legalistic economic demands. All such forms of resistance were organized autonomously outside the auspices of official unions. As has been argued persuasively by Feng Chen (2010), when strikes break out, union organizations do not represent their members, but rather serve as a mediator between the workers and management. This pattern certainly held during the upsurge of 2008-2009.

Before we turn to how worker protest evolved in 2010, we will first analyze the very different responses to the crisis from the unions and state.

\section{Getting Through the Hard Times Together?}

First of all, I must briefly address the relationship between the state and the unions. One cannot accept a view of the Party-state-union at all levels marching in unified lockstep as they are in fact complex, multi-tiered entities. And yet, 
at an institutional level, the union at every level remains formally and practically subordinate to the Party (Chen, 2009; Lau, 2003). Thus, when the state adopts a particular labor or industrial policy without public dissent on the part of union officials, the union is inevitably implicated in the policy. Since I am concerned with the practical divergence between labor and workers, this perspective necessitates an analysis of union response to be interwoven with that of state policy.

So what was the response of the state? In November of 2008, the government unveiled a massive RMB41 (US\$586 b) financial stimulus package. The overwhelming majority of this was devoted to infrastructure projects, many of which were an indirect subsidy to exporters. The central authorities announced that municipalities could freeze minimum wage increases and reduce employers' payments to social insurance, and RMB6 t (US\$878 b) in loans was made available to small and medium enterprises to expand their presence in overseas emerging markets (China Daily, 2009). An additional RMB15 b (US\$2.2 b) was approved in aid toward subsidizing interest-free loans for technology improvements in small firms (Associated Press, 2008a). The Ministry of Finance enacted tax rebates for more than 600 items, in effect eliminating the value added tax for many products (China Daily, 2009).

Of greatest concern was what appeared like a coordinated effort on the part of many regional governments to avoid enforcing their own laws. Perhaps the most extreme case was in January 2009, when Guangdong officials announced the 'Ten Advices' to help 'encourage enterprise development and ensure stable and relatively quick economic growth in Guangdong' (XinKuaiBao, 2009). The 'advice' said that enterprise bosses suspected of 'normal crimes' need not be arrested, and that enforcers should 'take circumstances into consideration' (XinKuaiBao, 2009). Additionally, the 'advice' clearly listed the 'six don'ts' for regulators handling cases related to business: 1) don't freeze company assets at will (suiyi); 2) don't seal up company accounts at will; 3) don't block company communication channels; 4) don't publish reports that will affect company image at will; 5) don't take key employees into custody at will; and 6) don't have a negative influence on companies completing important negotiations or completing production tasks because of handling legal cases (Guangzhou Ribao, 2009). One government official in Foshan went so far as to say that employers that violated the Labor Contract Law would 'not be fined, and will not have their operating licenses revoked' (HuaxiaShibao, 2009).

The exact involvement of the ACFTU and its subordinate unions in the formulation of these policies cannot be known. In private conversations, some trade union leaders did express dissatisfaction with the state's response to the crisis. ACFTU leadership publicly stated that they were opposed to canceling the minimum wage and said that the Labor Contract Law should continue to be implemented (Caijing, 2009). To a certain extent, the unions' (and state's) preoccupation with stability resulted in an overlap between their interests and those of workers in that layoffs were seen as increasing the chances of social upheaval. And yet, even in instances when the union attempted to protect the interests of its constituents, two prominent features emerged. First of all, the unions refused to antagonize employers or use any coercive methods to protect workers; they consistently propagated a position that the best way to protect the rights of workers was to ensure enterprise growth. And second, the unions' response remained entirely severed from the wishes or active involvement of the membership. The response was administrative or based on union leadership attempting to persuade employers to reduce layoffs, both processes that fully excluded the membership. 
Announced in December 2008, the key platform of the trade unions was the 'mutually agreed upon action', which called for enterprises and workers to 'get through the hard times together' and to build a 'harmonious enterprise'. The policy entailed the union asking employers to 'not lay off workers/reduce layoffs, not reduce wages/minimize wage reductions, and conduct layoffs and wage reductions according to legal collective negotiations', as characterized by the director of the ACFTU's collective contracts department (Liaowang, 2009). Employers were offered the opportunity to sign various types of documents where they would agree to a certain set of restrictions or principles related to layoffs and wage reductions. On the labor side, the union would represent workers in promising to:

share the risk with employers... to participate in labor competitions and technology improvements, to increase labor productivity and decrease the costs of production, to actively reduce waste and be efficient, and get through the hard times together with the enterprise in trying to find new and better ways of doing things. (Liaowang, 2009)

Additionally, the union would promise to:

lead workers to rationally protect their rights, to educate workers not to affect production, work order, or social stability by engaging in work stoppages, slowdowns, or collective appeals. This is to ensure normal production and operation of the enterprise and work order. (Liaowang, 2009)

Subsequently, many unions around the country announced various 'mutually agreed upon actions'. In each place, these agreements were characterized by weakly worded requests for employers, while repeatedly stressing that workers must not take any collective action to defend their interests. Representatives from Guangdong's Labor Bureau, Employer Association and Federation of Trade Unions attended a press conference where they announced a mutually agreed-upon action that was entitled 'Taking the same boat together to protect growth, making great accomplishments to encourage development' (Jin Yang Wang, 2009). Employers facing economic difficulty were exhorted to provide workers with training or rearrange shifts and rest days so as to avoid layoffs. Workers were told to 'consider the situation as a whole', and to use 'rational, legal methods, and self-consciously uphold social harmony and stability' (Jin Yang Wang, 2009) when trying to resolve conflicts. Guangdong Federation of Trade Unions chair Deng Weilong encouraged employers to 'work hard' to avoid layoffs and wage reductions, but that if such steps were necessary, they must first engage in 'equal negotiations' before taking action.

And yet, as has already been discussed, massive layoffs, non-payment of wages and subsequent labor insurgency did take place. This of course caused great consternation to union leadership, leading to one particularly notable outburst from ACFTU second-in-command Sun Chunlan. Discussing the issue of social instability resulting from unemployment, vice-chair Sun said that they must be vigilant in guarding against 'foreign and domestic enemy forces that use difficulties in enterprises to infiltrate and destroy the ranks of migrant workers' (XinJing Bao, 2009). The message was clearly sent to workers themselves as much as it was to other union officials.

Despite the 'stick' of such thinly veiled threats and the 'carrot' of the 'getting through the hard times together' policy, the union was of course unable to tamp down worker resistance. The number of strikes, riots and officially 
mediated labor disputes skyrocketed in 2008; despite a subsequent return to growth in the export sector, labor unrest did not decline significantly in 2009. The economic crisis had intensified a trend of increasing insurgency, and higher levels of the union were unsure of how to respond.

\section{The Honda Crucible}

This background of expanding worker insurgency is crucial in understanding the strike wave of spring/summer 2010. In addition to the high political and economic costs of repression, labor bureaus and courts were overwhelmed with cases, all of which took a serious toll on the state. At the same time, the crisis had resulted in a weakening of consumer demand in the developed world, giving the central government greater incentive to push for an increase in wages and domestic consumption. Thus, when hundreds of workers at the Nanhai Honda Transmission plant walked off the job in a wildcat strike on 17 May, the central government provided implicit support by allowing extensive media coverage. Both the central leadership and the provincial union federation became interested in using bottom-up pressure from the strike to implement a regularized system of collective bargaining.

The strike had been planned by just a few workers, but very quickly spread throughout the various different departments at the plant. Initially, the demand that workers put forward was to increase base wages to RMB2000/month (US\$294), RMB800 more than their existing salary. Shortly after the strike began, management talked with workers and convinced them to go back to work, promising them that they would consider the demand and then respond promptly. The higher-level trade union immediately conducted an investigation and concluded that 'according to relevant regulations, we did not discover that the factory is violating the law' (Caixin, 2010a). Negotiations began on 21 May, by which time the workers had formalized their demands. In addition to demanding the wage increase, they called for a 'reorganization' of the enterprise union (i.e. new election for union chair), the rehiring of two strike leaders that had been fired, and a guarantee that there would be no retaliation against strikers. Then, on 22 May, a Saturday, workers became frustrated with management's inaction and once again started the strike.

Management had the weekend to consider their options and on Monday 24 May offered not to increase wages, but to add RMB55 to the workers' living subsidies. The local government and trade union supported this offer in the hopes that the stand-off would end quickly. Workers were outraged by the low counter-offer and rejected it out of hand. Things became increasingly tense for Honda on 25 May, when all four of their assembly plants in China were forced to stop production because of the strike in the Nanhai plant. With management becoming desperate, on 26 May they offered workers about $50 \%$ of what they were asking in wage increases if they promised to return to work the following day. Sticking with their original demands, workers yet again rejected this offer. As the strike dragged on, reports emerged that some portion of the workforce was willing to take the offer and return to work. It is unclear to what extent this is true, but there were certainly several hundred workers who refused to end the strike, and production was therefore not resumed. In-depth media coverage continued unabated, and the local government began to feel immense pressure to resolve the conflict.

What happened on 31 May was a crucial turning point in the strike. That morning, a group of union officials from 
the Shishan Township Federation of Trade Unions (the union federation immediately superior to the Nanhai Honda enterprise union) dispatched approximately 100 people wearing union badges and yellow hats to the Honda factory. Their apparent mission was to convince the strikers to return to work. When the group from the union confronted workers inside the factory gates, words very quickly got heated. According to worker accounts, the people from the union hit several workers. Nobody was seriously injured, but at least one worker's face was cut and bleeding. Images of uniformed workers tussling with the union officers spread quickly throughout the country, and a strong symbolic statement was made.

The following day, the Shishan Township Federation of Trade Unions sent an open letter to the workers. It said: 'If people feel that some of the methods used in yesterday's incident were a bit difficult to accept, we apologize.' But then went on to admonish workers for refusing to accept the offer that management had made, and said that striking workers had 'already damaged the interests of the majority of employees'. In a final attempt at damage control, the letter closed by saying: 'Please trust the union. Trust each level of Party officials and government. We will definitely uphold justice' (Caixin, 2010a).

On 4 June, the worker representatives were joined by a labor scholar from Beijing who served as their legal counsel. Negotiations went late into the night, and an agreement was eventually struck. Regular workers were to receive wage increases of approximately RMB500, bringing their monthly wages above RMB2000. The underpaid 'interns' that work alongside regular workers saw their wages increase by more than RMB600, an increase of more than 70\%. And officers from the Guangdong Federation of Trade Unions agreed to preside over new elections in the enterprise union.

Even before the strike at Nanhai ended, worker insurgency cascaded through the nation's auto industry, even spilling over into other industrial sectors. In each case, the primary demand was for large wage increases. While the insistence on union reorganization was not highlighted as much in these other struggles, it was included as a demand by many strikers. Workers walked off the job in two other nearby Honda suppliers, again severely disrupting production. At one such plant, the Guli Lock Factory in Zhongshan, workers marched in public and blocked roads. As early as 28 May, Hyundai Automobile workers walked off the job. Just as had been the case at Honda, a strike wave rippled through Toyota's China operations from Tianjian in the north to Guangzhou in the south, causing several plants to stop production. In the northern city of Dalian, a strike wave tore through a development zone, involving 70,000 workers and affecting 73 enterprises (Caixin, 2010b).

In the aftermath of the strike wave, pro-reform elements in the union began calling for new legislation. In particular, Guangdong province began considering a measure that would make it much easier for employees to demand collective bargaining, and which would compel employers to negotiate. Additionally, many union leaders began to call for legalizing strikes. While these laws have been put on hold at the time of writing, the fact that they emerged as public positions in the first place is directly attributable to ongoing labor unrest. Most directly relevant was that the union and workers at Nanhai Honda entered a subsequent round of collective bargaining in late winter 2011. With some of the 
negotiators drawn from directly elected representatives, substantive back-and-forth negotiation took place. Although the representatives did not get their initial demand of an RMB800/month wage increase, they did secure an increase of RMB611. While many regular workers remained suspicious of the union, it appeared as if some approximation of real collective bargaining was being established - albeit in very exceptional circumstances.

\section{Post-socialist Unions and Economic Crisis}

What is the connection between the divergent responses of unions and workers during the 2008-2009 crisis and the outcomes of the Nanhai strike? We can see that the union's response of 'getting through the hard times together' was a failure, and that, by and large, employment relations were incredibly unstable. Ongoing and expanding worker resistance caused great concern for the central state and for unions. When the strike broke out at Nanhai, we see that the lowest levels of the union maintained a single-minded obsession with getting workers back on the line, regardless of the outcome, and that they were even willing to resort to physical coercion. On the other hand, higher-ups (specifically the Guangdong Federation of Trade Unions, but also central government leaders) were willing to give tacit support to the strikers to indicate to other employers that they should consider wage increases. Following the Nanhai strike, much of union officialdom took the opportunity to argue that unions needed to be more attentive to the needs of the membership, and that legal rights to collective bargaining and striking should be considered. While the Nanhai strikers' demand to re-elect their enterprise chair was denied, they did hold team-level elections and successfully engaged in two rounds of collective bargaining. More generally, the central government began pushing for increases in the minimum wage, and there were widespread reports of rising wages across the board. ${ }^{2}$ These changes witnessed in 2010 would not have occurred without the background of the threat to social stability posed by the expanded worker resistance of 20082009.

More generally, how can the experiences of 2008-2010 in China inform theories of post-socialist unionism? Unions operating under conditions of appropriated representation are unlikely to see economic crisis as an 'opportunity', as it only serves to heighten discord. In China, we saw the ACFTU behaving precisely as one might expect engaging in administrative and lobbying efforts with employers and government, while consistently warning workers away from taking collective action. Subordinate to the state in the political sphere and management at the enterprise

level, the union could not effectively defend the interests of its membership. We can, then, see that crisis heightens the tensions inherent in post-socialist unions as it results in intensified livelihood struggles among workers, which oftentimes take place completely independently from union control. Increased autonomous worker activity in turn forces fixes and adjustments on the part of the representatives - as clearly evidenced in China by the outcomes at Honda and subsequent proposals for legislative reform. In short, economic crisis began by intensifying the conflict within the relationship of appropriated representation, thereby resulting in a transformation of this very relationship.

But what is specific about the situation in China, and how does it compare to worker-union relations in other non-democratic political environments? Labor politics in China are distinguished by the state's greater commitment and capacity to use repression at the first signs of independent organization. For instance, while the military regime in Korea 
was certainly opposed to independent unionism, such unions were able to emerge and build political power, even before democratization in the late 1980s. A similar dynamic existed under martial law-era Taiwan, although such organizations were not as powerful or militant as their Korean counterparts. And in contemporary Vietnam, the government appears to have a much more relaxed attitude toward independently organized strikes. Deprived of other avenues of organized expression, the consequence is that Chinese workers will not be able to ignore the official union in the way that has been more possible in other political contexts. As a result, we might reasonably expect greater worker contestation within ACFTU organizations, particularly at the enterprise level, as other options can only be pursued at great risk.

I envision three possible paths for future developments: 1) reform, in which ACFTU unions become more democratic and derive more of their legitimacy from the membership rather than from state recognition, thereby reducing autonomous resistance and bringing union and worker practices into greater alignment (as we saw in the Honda strike, worker demands for democratic union elections are likely to increase); 2) expanded radicalism, in which the unions fail to change, but worker insurgency continues to expand in scope and intensity, potentially leading either to democratic outcomes or social breakdown; and 3) stalemate, in which unions do not reform but worker insurgency levels out (because of capital relocation, heightened repression, marginally improved material conditions, etc.). It is true that China fared relatively well in the economic crisis of 2008-2009. But given its deep integration into global capitalism and ongoing uncertainty in the world's economy, future shocks of an equal or greater severity are possible. In the meantime, we can expect ongoing divergence and conflict between union representatives and workers.

\section{Acknowledgments}

I would like to thank Byoung-Hoon Lee and Russell Lansbury for their hard work in putting together this special edition. I am additionally grateful for the comments from my peer reviewers as well as the assistance of Hao Zhang.

\section{Funding}

The author would like to thank the University of California's Pacific Rim Research Program for supporting this research.

\section{Notes}

1 Note the inconsistency in the title of the cited article, which claims that 26 million became unemployed. The actual estimate was 20 not 26 million.

2 It should be noted, however, that there is also evidence that there have still not been increases in real wages, as inflation was rising quickly in this period (Caijing, 2011).

\section{References}

Agence French-Presse (2008) Workers stage sit-in at Shanghai factory. 9 December.

Anderson J (2007) Is China export-led? Asian Focus 27: 1-12.

Associated Press (2008a) China to give aid to companies to cope with crisis. 13 December. Associated Press (2008b) 
China's output slows further. 16 December.

Associated Press (2008c) Protest by suitcase workers sent packing in China. 20 December. Baccaro L (2010) Does the global financial crisis mark a turning point for labour? Socio-Economic Review 8: 341-376.

Birnbaum N (2010) Is social democracy dead? The crisis of capitalism in Europe. New Labor Forum 19: $24-31$.

Bloomberg (2008) China boomtown withers as buyers push worker rights. 9 December.

Caijing (2009) quanguo zonggonghui: bu zancheng quxiao zuidi gongzi biaozhun [ACFTU does not support the cancellation of the minimum wage]. 10 March.

Caijing (2011) Real wages on decline in China. 28 September.

Caixin (2010a) bentian duzi lingbujian chang bagong zhi guangben ting chan [Strike at Honda owned parts factory leads to stopped production at Guangzhou Honda]. 27 May.

Caixin (2010b) dalian tinggong chao 7 wan ren canyu boji 73 jia qiye, yi gongzi zhang 34.5\% gaozhong [70k take part in Dalian strike wave affecting 73 enterprises, receive a 34.5\% wage increase]. 20 September.

Chan CK-C (2010) The Challenge of Labour in China: Strikes and the Changing Labour Regime in Global Factories. London: Routledge.

Chen F (2003) Between the state and labour: The conflict of Chinese trade unions' double identity in market reform. The China CQuarterly 176: 1006-1028.

Chen F (2004) Legal mobilization by trade unions: The case of Shanghai. The China Journal

52: $27-45$.

Chen F (2007) Individual rights and collective rights: Labor's predicament in China. Communist and Post-Communist Studies 40: 59-79.

Chen F (2009) Union power in China: Source, operation, and constraints. Modern China 35: 662-689.

Chen F (2010) Trade unions and the quadripartite interactions in strike settlement in China. The China CQuarterly 201: 104-124.

China Daily (2009) Exporters gets sops to fight crisis. 6 June.

Clarke S and Pringle T (2009) Can party-led trade unions represent their members? Post-Communist Economies 21(1): 85-101.

Clarke S, Lee C-H and Li Q (2004) Collective consultation and industrial relations in China. British Journal of Industrial Relations 42: 235-254.

Crowley S (2004) Explaining labor weakness in post-communist Europe: Historical legacies and comparative perspective. East European Politics and Societies 18(3): 394-429. 
Crowley S and Ost D (2001) Workers after Workers' States: Labor and Politics in Postcommunist Eastern Europe. Lanham, MD: Rowman \& Littlefield.

Guangzhou Ribao (2008) dongguan laozi jiufen yinfa qunti shijian 500 ren daza jingche [Labor conflict in Dongguan leads to mass incident, 500 people smash police cars]. 26 November.

Guangzhou Ribao (2009) qiye lingdao fan qingzui ke zhuo qing zanhuan cha ban [Take into consideration circumstances and postpone the investigation of enterprise bosses that commit small crimes]. 7 January.

He D and Zhang W (2010) How dependent is the Chinese economy on exports and in what sense has its growth been export-led? Journal of Asian Economics 21: 87-104.

Howell J (2006) New democratic trends in China? Reforming the All-China Federation of Trade Unions. Working paper 263, Institute of Development Studies, University of Sussex.

HuaxiaShibao (2009) dongguan san fen zhi yi qiye yanchi kaigong, fan yue nongmingong gang wei nan mi [1/3 of Dongguang enterprises delay re-opening, migrants returning to Guangdong have difficulty finding work]. 14 February.

Jin Yang Wang (2009) qiye jianxin yao tong zhigong xieshang, 'ling gongzi' zhaopin weifa [Enterprises have to negotiate with employees to reduce wages, 'zero salary' is illegal]. 27 March.

Lau R (2003) The habitus and 'logic of practice' of China's trade unionists. Issues \& Studies 39: $75^{-10} 3$.

Lee CK (2007) Against the Law: Labor Protests in China's Rustbelt and Sunbelt. Berkeley, CA: University of California Press.

Lee LT (1986) Trade Unions in China: 1949 to the Present. Singapore: Singapore University Press.

Liaowang (2009) zhongguo gonghui tuidong 'gongtong yueding xingdong': huajie laozi maodun kao xieshang [Chinese unions promote 'mutually agreed upon action': Resolving labor disputes depends on negotiation]. 22 June.

Lipset SM, Trow M and Coleman J (1956) Union Democracy. New York, NY: Free Press.

Marx K (1978) The communist manifesto. In: Tucker RC (ed.) The Marx-Engels Readers. New York, NY: Norton, 469-500.

Michels R (1962) Political Parties: A Sociological Study of the Oligarchical Tendencies of Modern Democracy. New York, NY: Dover.

Nanfangdushibao (2008) dongguan liangyue 117 jia qianxin qiye taoni [117 enterprises with wage arrears in Dongguan go into hiding in two months]. 19 November.

Nanfeng Chuang (2009) jiuye weiji huo zhi quntixing shijian fashengjilv zengjia [Problems with employment leads to increase in mass incidents]. 3 March.

National Bureau of Statistics (NBS) and Ministry of Human Resources and Social Security (MOHRSS) (2010) China Labor Statistical Yearbook 2010. Beijing: China Statistics Press.

Ng SH and Warner M (1998) China's Trade Unions and Management. New York, NY: St. Martin's Press. 
Reuters (2008) South Korean investors quit China over rising costs. 22 March.

Stepan-Norris J (1997) The making of union democracy. Social Forces 76(2): 475-510.

The Guardian (2009) Downturn in China leaves 26 million jobless. 2 February.

The Sunday Times (2009) Violent unrest rocks China as crisis hits. 1 February.

Tilly C (2010) An opportunity not taken... yet: U.S. labor and the current economic crisis. Working USA 14: 73-85.

Voss K and Sherman R (2000) Breaking the iron law of oligarchy: Union revitalization in the American labor movement. American Journal of Sociology 106: 303-349.

Wall Street Journal (2009) Factory closures strain China's labor law. 16 January.

Wang H, Appelbaum RP, Degiuli F, et al. (2009) China's new labour contract law: Is China moving towards increased power for workers? Third World Quarterly 30: 485-501.

Weber M (1946) Bureaucracy. In: Gerth HH and Mills CW (eds) From Max Weber: Essays in Sociology. New York, NY: Oxford University Press.

Weber M (1978) Economy and Society. Berkeley, CA: University of California Press.

Xin Jing Bao (2009) zong gonghui: yanfang diduishili dui nongmingong qunti shentou pohuai [ACFTU: Be vigilant in guarding against enemy forces infiltrating and destroying migrant groups]. 18 February.

XinKuaiBao (2009) guangdong guiding qiye laozong she yiban fanzui ke bu jubu [Guangdong stipulates that bosses suspected of normal crimes don't have to be arrested]. 7 January.

Yangchengwanbao (2008) 15661 small and medium enterprises in Guangdong close, claim that it is not a 'wave of closings'. 17 December.

Yu X (2008) Workplace democracy in China's foreign-funded enterprises: A multilevel case study of employee representation. Economic and Industrial Democracy 29: 274-300. 